\title{
Modelling of groundwater contamination by landfill leachate
}

\author{
S. Top, G. Varank, A. Demir, E. Sekman \& M. S. Bilgili \\ Department of Environmental Engineering, \\ Yildiz Technical University, Turkey
}

\begin{abstract}
The objective of this study is to investigate the transport of phenolic compounds existing in leachate through landfill liner systems by assessing the groundwater quality. Four identical pilot-scale landfill reactors with different alternative composite liners ( $2 \mathrm{~mm}$ high-density polyethylene (HDPE) geomembrane, $10+$ $10 \mathrm{~cm}$ compacted clay, $2-\mathrm{cm}$-thick bentonite and $10+10 \mathrm{~cm}$ compacted clay liner (CCL), 2-cm-thick zeolite and $10+10 \mathrm{~cm}$ CCL) were simultaneously operated for a period of about 540 days for this purpose. Wastes representing Istanbul municipal solid wastes were disposed in the reactors. To represent bioreactor landfills, reactors were operated by leachate recirculation. Phenolic compounds of leachate were analyzed by using Gas Chromatograph. The change of phenolic compounds concentration in groundwater samples were modeled by using modified Gompertz equation.
\end{abstract}

Keywords: modelling, leachate, phenolic compounds, groundwater contamination.

\section{Introduction}

Leachates from municipal solid waste (MSW) landfills and various discarded products contain a wide mixture of chemical pollutants as dissolved organic matter; inorganic macro components; heavy metals; xenobiotic organic compounds [1]. The issue of xenobiotic organic compounds (XOCs) in landfill leachates have been addressed in a number of studies [1-6]. The XOCs include a variety of aromatic hydrocarbons, phenols, chlorinated aliphatics, pesticides, and plastizers. Among them, phenol is the precursor to the synthesis of many organic compounds and is of high concern because of potential toxicity [7]. Phenol and 
substituted phenols are common transformation products of several pesticides. Many substituted phenols, including chlorophenols, nitrophenols, and cresols, have been designated as priority pollutants by the U.S. Environmental Protection Agency [8].

Landfills constitute a potential risk to the quality of receiving water bodies, such as surface water or groundwater [2-4, 9]. For this reason, MSW landfills have been identified as one of the major threats to groundwater resources [10]. The impact of landfill leachate on the surface and groundwater has given rise to a number of studies in recent years [11-16].

The liner system is one of the most important elements of a modern engineered landfill. There are two pathways for contaminant transport through composite liners: advection and diffusion of inorganic and organic solutes through defects in the geomembrane and subsequently through the soil liner; and diffusion of organic solutes through the intact geomembrane and subsequently through the soil liner $[16,17]$. Due to its high strength, impermeability, and resistance to compounds, the high density polyethylene (HDPE) geomembranes are the most widely used components of modern liner systems in solid waste landfills. However, many studies have shown that geomembranes are essentially impervious to diffusion of inorganic contaminants but organic compounds can readily penetrate through geomembranes in a short period of time $[18,19]$.

The other significant component of a modern liner system is soil liner generally comprising clay material. Early concerns regarding contaminant transport through clay liners focused on advective transport (e.g. contaminants migrating along with the flow of water through the clay) but recently researchers have concluded that diffusive transport (contaminant migration driven by the difference in concentration between the upper and lower sides of the liner) is often the dominant mode of contaminant transport through well-built liner systems [17, 20-22] including compacted clay liners [23-25], geosynthetic clay liners $[16,26]$ and, composite liners $[17,21,22]$.

Considering the above-mentioned facts, the specific objectives of this study are to evaluate the effectiveness of several landfill liner designs with regard to phenolic compounds transport through alternative landfill liners to groundwater by modeling the variations of the concentrations of phenolic compounds in groundwater samples using modified Gompertz equation.

\section{Materials and methods}

Four identical pilot-scale landfill reactors (R1, R2, R3 and R4) were simultaneously run for a period of about 540 days to investigate the nature of diffusive transport of the selected organic and advective transport of inorganic contaminants. All parts of the reactors were made of HDPE pressurized pipes with a wall thickness of $5 \mathrm{~mm}$. The diameter (DR), height (HR), effective volume (VE) and total volume (VT) of the reactors were $40 \mathrm{~cm}, 250 \mathrm{~cm}, 0.201$ $\mathrm{m} 3$ and $0.251 \mathrm{~m} 3$, respectively. The reactors were comprised from two parts with heights of 200 and $50 \mathrm{~cm}$ to install alternative liners. The bottom of the upper 
part of the reactors consisted of a $15-\mathrm{cm}$ gravel drainage with a perforated pipe $(2.5 \mathrm{~cm}$ diameter) inserted to collect and to discharge the generated leachate.

The reactors were operated by recirculation of leachate to represent bioreactor landfills, and four alternatives (2-mm high-density polyethylene (HDPE) geomembrane, clay, clay + bentonite, clay + zeolite) were employed for the reactor liners. The thicknesses of the clay layer, zeolite layer, bentonite layer were $10+10 \mathrm{~cm}, 2 \mathrm{~cm}$ and $2 \mathrm{~cm}$, respectively. The clay material and geomembrane used in this study was obtained from Komurcuoda Sanitary Landfill in $\left(41^{\circ} 8^{\prime} 41^{\prime \prime} \mathrm{N}, 2^{\circ} 22^{\prime} 21^{\prime \prime} \mathrm{E}\right)$ in Istanbul, Turkey. The leachate collection was performed by opening the discharge valve on a daily-basis at the beginning of the experiment, and at 1 or 2 week intervals for the following periods. The discharged leachate from each reactor was stored to use for recirculation. Distilled water was placed at the lower part of the four reactors simulating groundwater, and distilled water samples were obtained from the valves existing at the bottom. Landfill gas was collected via the perforated pipes, which were located in the center of each reactor ( $4 \mathrm{~cm}$ diameter and $170 \mathrm{~cm}$ height). Temperature probes were also located at $120 \mathrm{~cm}$ depths from the top of the waste to measure temperature variation in each landfill reactor. A detailed schematic of the experimental set-up is depicted in Fig. 1.

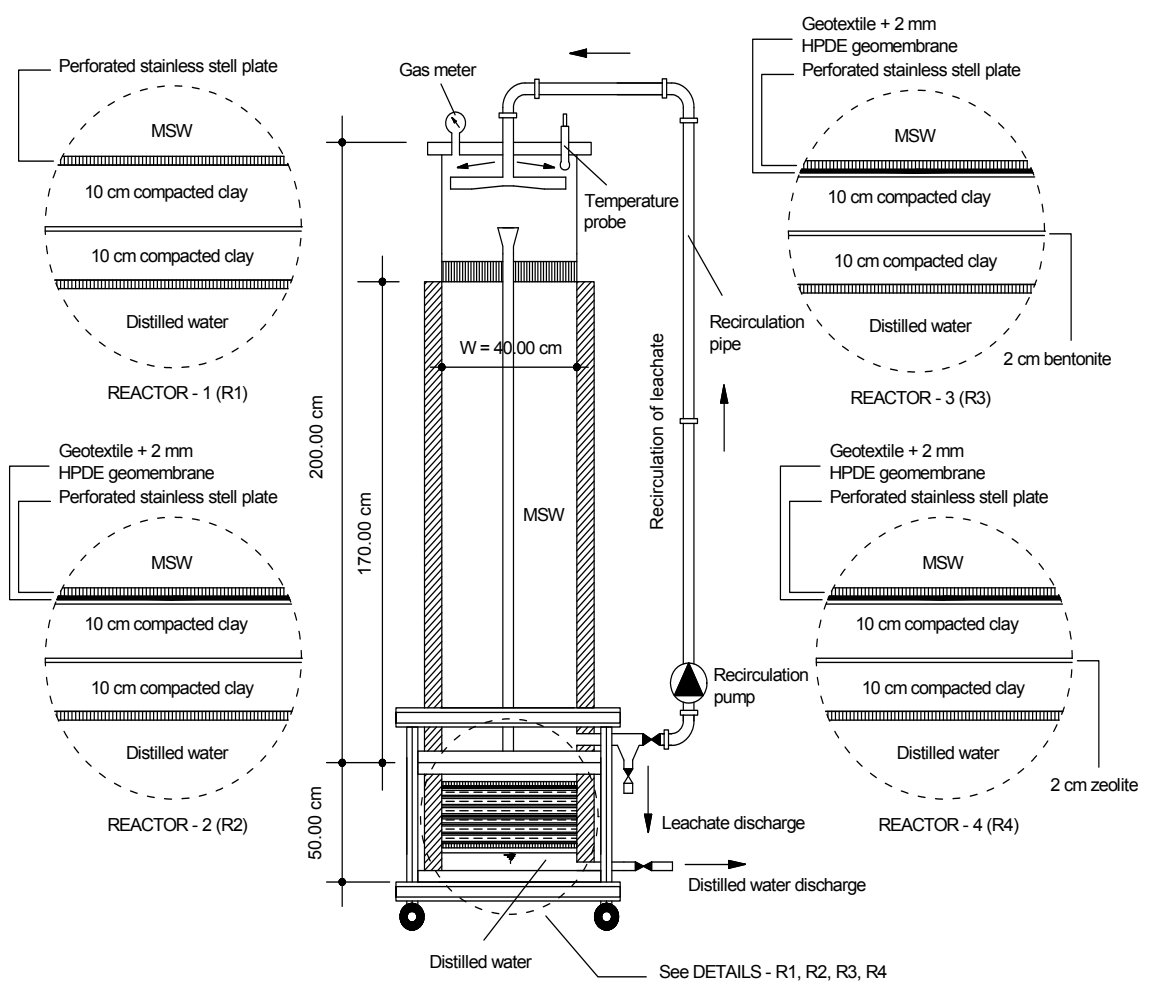

Figure 1: Schematic view of landfill bioreactors. 
The disposed municipal solid wastes in the landfill reactors were obtained from the Odayeri Sanitary Landfill $\left(41^{\circ} 14^{\prime} 8^{\prime \prime} \mathrm{N}, 28^{\circ} 51^{\prime} 16^{\prime \prime} \mathrm{E}\right)$ in Istanbul, Turkey. The average composition of solid waste samples collected from Odayeri Sanitary Landfill was $44 \%$ organic, $8 \%$ paper, $6 \%$ glass, $6 \%$ metals, $5 \%$ plastic, $5 \%$ textile, $9 \%$ nylon, $8 \%$ diaper, and $9 \%$ ash and others [27]. The reactors were filled with approximately $150 \mathrm{~kg}$ of fresh MSW.

To determine phenol and phenolic compounds in leachate, SPME method is used as conducted by Ribeiro et al. [28]. $85 \mu \mathrm{m}$ polyacrylate fiber (from SUPELCO), a SPME fiber holder (from SUPELCO) and $(0.25 \mathrm{~mm}$ x $30 \mathrm{~m} \mathrm{x}$ $0.25 \mu \mathrm{m}$ ) column are used for this method. The fiber was conditioned in the GC injector for $1 \mathrm{~h}$ at $250^{\circ} \mathrm{C}$. The vial capacity was $4 \mathrm{~mL}$, handling $2 \mathrm{~mL}$ of sample. The temperature and stirring velocity $(750 \mathrm{rpm})$ were controlled during extraction. The $\mathrm{pH}$ of the samples were adjusted $(\mathrm{pH}<2)$ with $\mathrm{H}_{2} \mathrm{SO}_{4}$ by using $\mathrm{pH}$ meter (Jenway 3040 Ion Analyser) and a $\mathrm{pH}$ probe (HI1230, Hanna Instruments). $\mathrm{Na}_{2} \mathrm{SO}_{4}$ was used to saturate samples. GC/FID analyses were carried out using a Varian 3900 Model GC/FID Gas Chromatograph with the helium carrier gas at $10 \mathrm{~mL} / \mathrm{min}$. Injector and detector temperatures are 250 and $320^{\circ} \mathrm{C}$, respectively. The temperature program is increased to $280^{\circ} \mathrm{C}$ at a heating rate of $6^{\circ} \mathrm{C} / \mathrm{min}$ and held at this temperature for $5 \mathrm{~min}$. Phenolic compounds are quantified by peak area using external standard method. Quantification is achieved using peak area calculations, and compound identification is partly carried out using correlations between retention times. EPA 8040A and EPA 8040B phenol calibration mixtures (from SUPELCO) containing eighteen phenols with an individual concentration of $2000 \mu \mathrm{g} / \mathrm{L}$ in isopropyl alcohol was used to obtain fourteen phenol derivatives.

\section{Results and discussion}

Maximum, mean and minimum concentrations of phenolic compounds in leachate and groundwater samples of anaerobic reactors are given in Table 1 and

Table 1: Maximum, mean and minimum concentrations of phenolic compounds in leachate samples of anaerobic reactors.

\begin{tabular}{cccccc}
\hline & & 2-CP & 4-NP & $\mathbf{2 , 4 , 6 - T C P}$ & PCP \\
\hline \multirow{4}{*}{ R1 } & Min & 12,70 & 1,11 & 3,24 & 10,32 \\
& Mean & 164,07 & 10,40 & 94,16 & 63,88 \\
& Max & 490,30 & 38,40 & 320,76 & 144,28 \\
\hline \multirow{2}{*}{ R2 } & Min & 12,40 & 1,34 & 10,56 & 5,32 \\
& Mean & 192,16 & 10,57 & 98,30 & 40,27 \\
& Max & 442,50 & 36,30 & 258,59 & 88,45 \\
\hline \multirow{4}{*}{ R3 } & Min & 2,20 & 0,16 & 0,57 & 1,41 \\
& Mean & 111,98 & 6,33 & 16,40 & 20,32 \\
& Max & 343,94 & 22,73 & 87,93 & 85,72 \\
\hline \multirow{2}{*}{ R4 } & Min & 2,20 & 0,24 & 0,51 & 0,62 \\
& Mean & 54,63 & 5,20 & 126,33 & 52,00 \\
& Max & 199,32 & 15,03 & 52,00 & 269,99 \\
\hline
\end{tabular}


Table 2: Maximum, mean and minimum concentrations of phenolic compounds in groundwater samples of the anaerobic reactors.

\begin{tabular}{cccccc}
\hline & & 2-CP & 4-NP & $\mathbf{2 , 4 , 6 - T C P}$ & PCP \\
\hline \multirow{2}{*}{ R1 } & Min & 0,63 & 0,58 & 0,78 & 1,99 \\
& Mean & 2,87 & 3,49 & 31,25 & 7,41 \\
& Max & 5,22 & 6,23 & 55,76 & 11,30 \\
\hline \multirow{2}{*}{ R2 } & Min & 0,54 & 0,29 & 0,58 & 1,74 \\
& Mean & 8,13 & 4,24 & 22,32 & 11,16 \\
& Max & 14,48 & 5,68 & 36,17 & 15,95 \\
\hline \multirow{2}{*}{ R3 } & Min & 0,22 & 0,00 & 0,55 & 0,42 \\
& Mean & 2,16 & 1,59 & 2,06 & 2,94 \\
& Max & 3,64 & 2,85 & 3,47 & 4,67 \\
\multirow{2}{*}{ R4 } & Min & 0,55 & 0,35 & 0,24 & 0,46 \\
& Mean & 2,01 & 1,67 & 33,04 & 12,76 \\
& Max & 3,99 & 1,94 & 58,06 & 29,94 \\
\hline
\end{tabular}

Table 3: Gompertz model coefficients for phenolic compounds in groundwater samples of anaerobic reactors.

\begin{tabular}{|c|c|c|c|c|c|c|}
\hline \multirow{2}{*}{ Reactor } & \multirow{2}{*}{ PhenolicCompound } & \multicolumn{5}{|c|}{ Gompertz model coefficients } \\
\hline & & $\mathbf{A}_{\mathbf{0}}$ & $\mathbf{A}_{\max }$ & $\mathbf{m}$ & $\mathbf{L}$ & $\mathbf{R}^{2}$ \\
\hline \multirow{4}{*}{$\bar{\simeq}$} & $2-\mathrm{CP}$ & 0.946 & 4.413 & 0.0185 & 185.8 & 0.960 \\
\hline & 4-NP & 0.859 & 5.065 & 0.0253 & 158.8 & 0.971 \\
\hline & 2,4,6-TCP & 0.905 & 53.62 & 0.2688 & 134.8 & 0.960 \\
\hline & PCP & 2.576 & 7.980 & 0.0290 & 73.66 & 0.781 \\
\hline \multirow{4}{*}{$\cong$} & 2-CP & 1.130 & 13.18 & 0.0607 & 144.2 & 0.956 \\
\hline & 4-NP & 0.365 & 5.076 & 0.0305 & 50.26 & 0.926 \\
\hline & 2,4,6-ТCP & 0.294 & 36.96 & 0.1226 & 65.00 & 0.961 \\
\hline & PCP & 2.620 & 12.02 & 0.0565 & 51.64 & 0.836 \\
\hline \multirow{4}{*}{$\ddot{q}$} & $2-\mathrm{CP}$ & 0.214 & 3.572 & 0.0106 & 77.49 & 0.881 \\
\hline & 4-NP & 0.007 & 2.908 & 0.0078 & 58.06 & 0.808 \\
\hline & 2,4,6-ТCP & 0.631 & 1.923 & 0.0081 & 55.60 & 0.842 \\
\hline & PCP & 1.249 & 3.040 & 0.0091 & 68.11 & 0.721 \\
\hline \multirow{4}{*}{$\underset{\simeq}{ \pm}$} & 2-CP & 0.776 & 2.971 & 0.0104 & 176.0 & 0.926 \\
\hline & 4-NP & 0.068 & 1.471 & 0.0078 & 47.60 & 0.748 \\
\hline & 2,4,6-ТCP & 0.002 & 55.25 & 0.2231 & 92.15 & 0.946 \\
\hline & PCP & 1.322 & 22.82 & 0.0703 & 106.8 & 0.703 \\
\hline
\end{tabular}

Table 2. As seen from Table 1 and Table 2, 2-CP and 4-NP concentrations in leachate samples of R1 and R2 reactors were determined to be higher. Higher 
concentrations of 2-CP and 4-NP in groundwater samples of R1 and R2 reactors can be explained by higher concentrations of these compounds in leachate samples. 2,4,6-TCP and PCP concentrations of groundwater samples of R4 reactor were determined to be higher because of high concentrations of these compounds in leachate samples. In R3 reactor concentrations of phenolic compounds in groundwater samples were found to be lower when compared with other reactors. This can be explained by adsorption of contaminants by bentonite material used as a liner component in this reactor.

2-CP concentrations in groundwater samples were determined in the range of $0.63-5.22 \mu \mathrm{g} / \mathrm{L}$ in $\mathrm{R} 1$ reactor, $0.5-15 \mu \mathrm{g} / \mathrm{L}$ in $\mathrm{R} 2$ reactor, $0.22-3.64 \mu \mathrm{g} / \mathrm{L}$ in $\mathrm{R} 3$ reactor and $0.55-3.99 \mu \mathrm{g} / \mathrm{L}$ in $\mathrm{R} 4$ reactor during the study. Transport percentage of 2-CP from landfill leachate to groundwater was determined as $1.75 \%, 4.23 \%$, 1.93 and $3.69 \%$ in $\mathrm{R} 1, \mathrm{R} 2, \mathrm{R} 3$ and $\mathrm{R} 4$ reactors respectively. 2,4,6TCPconcentrations were determined in the range of $0-60 \mu \mathrm{g} / \mathrm{L}$ in $\mathrm{R} 1$ reactor, $0.58-36.17 \mu \mathrm{g} / \mathrm{L}, 0.61-4 \mu \mathrm{g} / \mathrm{L}$ in $\mathrm{R} 3$ reactor, and $0.24-58.06 \mu \mathrm{g} / \mathrm{L}$ in $\mathrm{R} 4$ reactor,

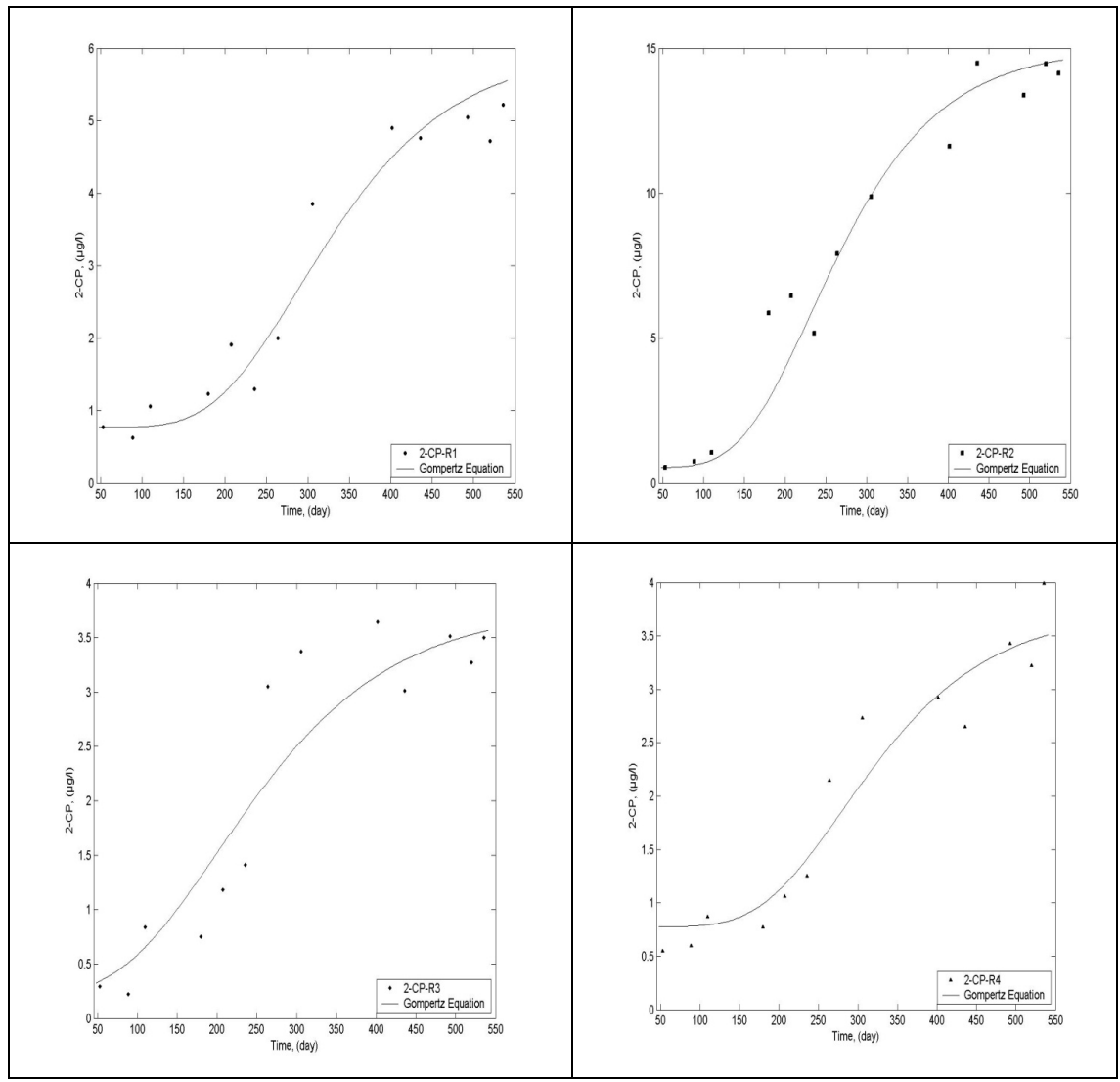

Figure 2: $\quad$ Gompertz model for 2-CP concentrations in groundwater samples of anaerobic reactors. 
respectively. Based on the experimental results, 2,4,6-TCP concentration measured in $\mathrm{R} 3$ reactor was determined to be lower than the other reactors. It was found that transport percentages of 4-NP in R1 and R2 reactors were higher than those in R3 and R4 reactors, which have bentonite and zeolite in liner systems. These results can be attributed to the adsorption capacity of bentonite and zeolite materials. PCP concentrations were determined in the ranges of 2-12 $\mu \mathrm{g} / \mathrm{L}, 1.74-15.9 \mu \mathrm{g} / \mathrm{L}, 0.42-4.7 \mu \mathrm{g} / \mathrm{L}$, and $0.46-30 \mu \mathrm{g} / \mathrm{L}$ in R1, R2, R3 and R4 reactors, respectively. PCP transport in R3 reactor, with a bentonite layer in addition to compacted clay liner and geomembrane, was found to be lower than those in R2 and R4 reactors, and close to R1 reactor. But PCP transport in R4 reactor with zeolite layer was determined to be the higher than R1 and R3 reactors and close to R2 reactor having a geomembrane and clay liner. The reason of this may be attributed to the higher PCP concentration of leachate generated in $\mathrm{R} 4$ reactor.

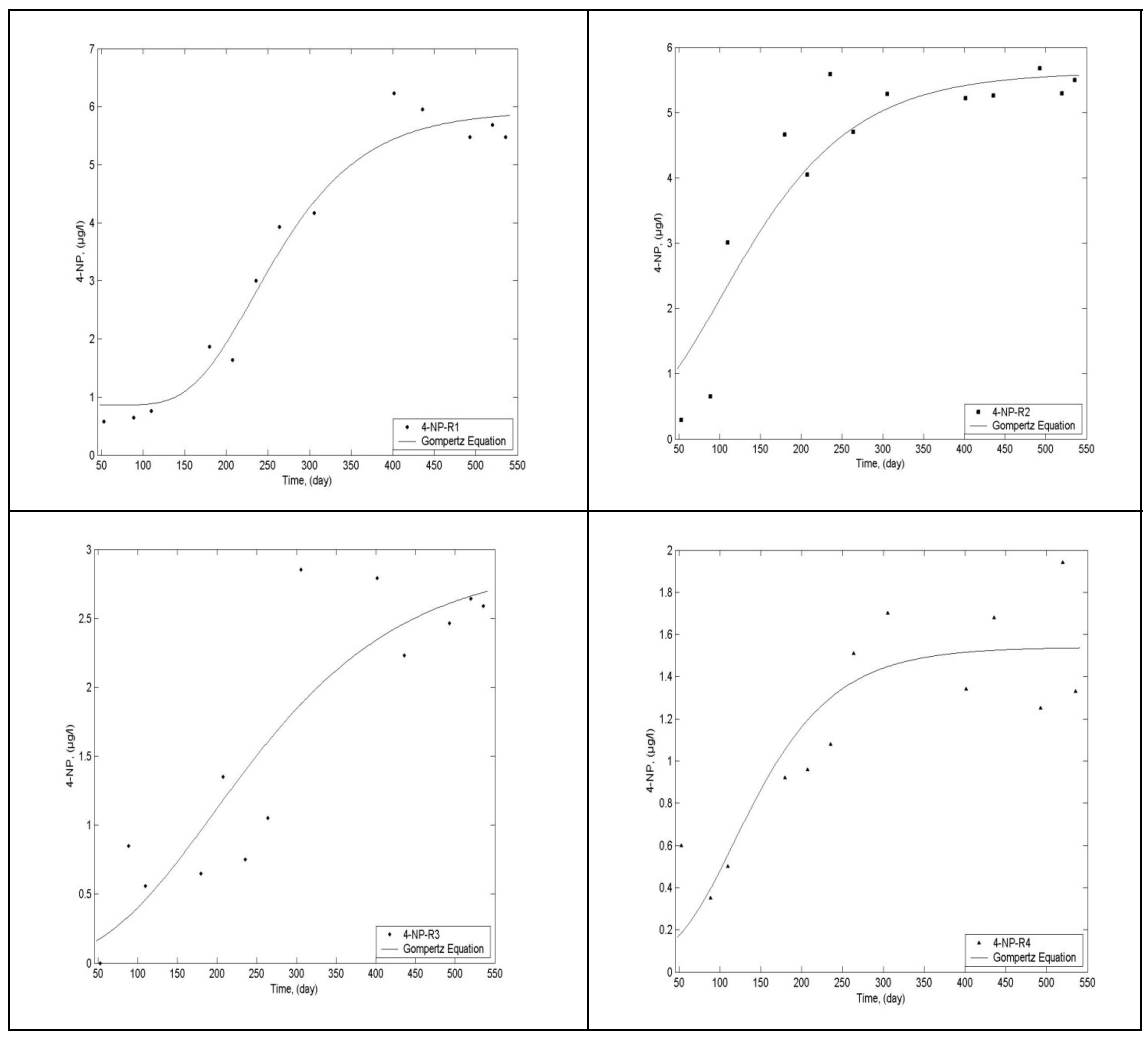

Figure 3: Gompertz model for 4-NP concentrations in groundwater samples of anaerobic reactors. 
The variations of phenolic compounds in groundwater samples by time was modelled by using modified Gompertz equation. This equation was given as follows;

$$
A=A_{0}+A_{\max } \cdot \exp \left[-\exp \left(\frac{m \cdot \exp (1)}{A_{\max }} \cdot(L-t)+1\right)\right]
$$

where, $\mathrm{A}_{0}$ is the concentration phenolic compound at the beginning of the experimental study, A is the concentration phenolic compound, Amax is the maximum concentration phenolic compound, $\mathrm{m}$ is the slope, and $\mathrm{L}$ is the time for the beginning of the increase of the concentration phenolic compound. Experimental and model results for the variations of concentration phenolic compound by time and model coefficients calculated are given in Figures 2-5 and Table 3 , respectively.

Variations of 2,4,6-TCP and 2-CP concentrations in all of the reactors by time fits Gompertz Equation Model with higher correlation coefficients. Variation of PCP concentrations in all of the reactors by time fits Gompertz Equation Model

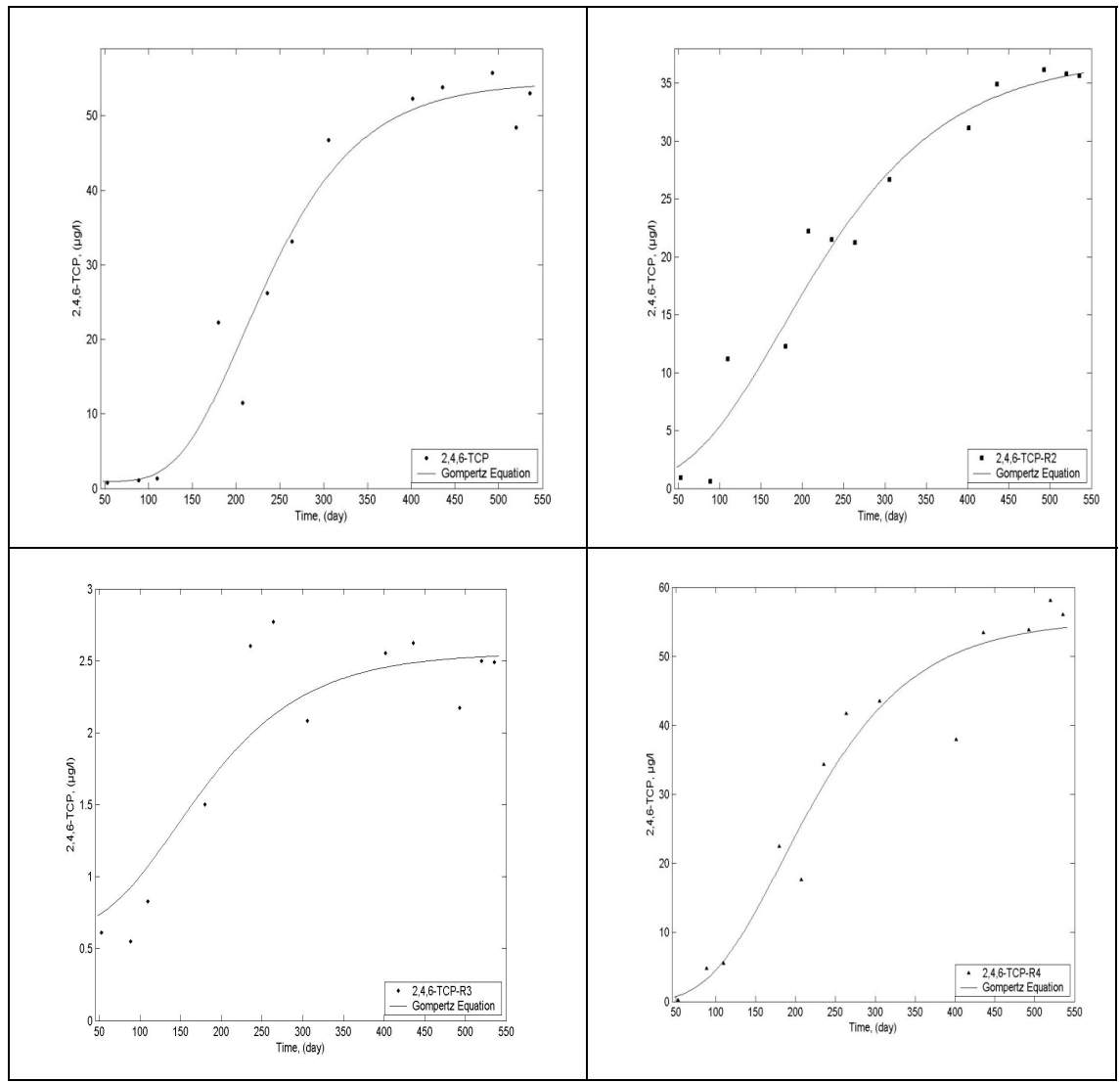

Figure 4: Gompertz model for 2,4,6-TCP concentrations in groundwater samples of anaerobic reactors. 


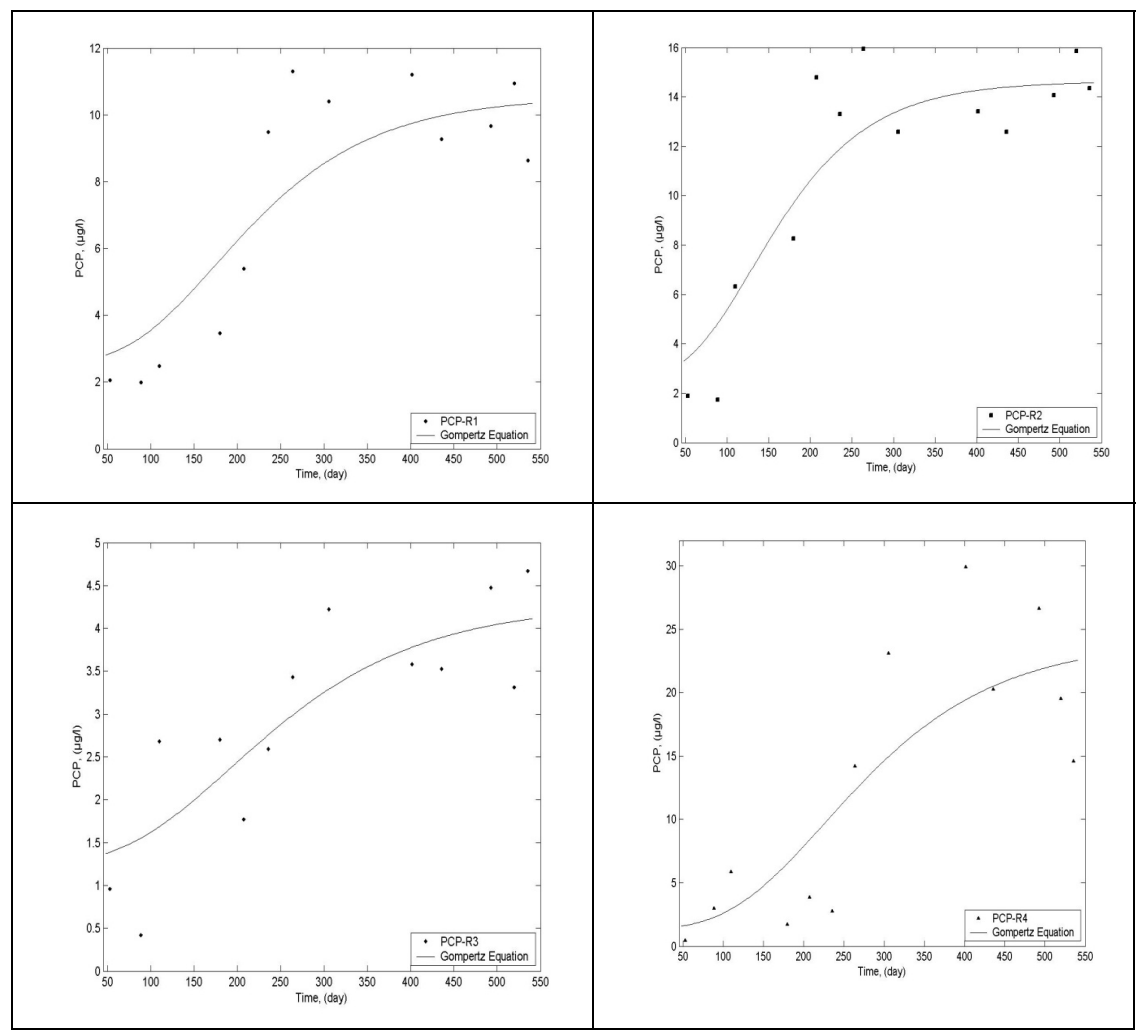

Figure 5: Gompertz model for PCP concentrations in groundwater samples of anaerobic reactors.

with the lowest correlation coefficients. As seen from Table1 that highest Amax values representing maximum concentration were calculated for 2,4,6-TCP. $\mathrm{A}_{0}$ values of PCP were found to be higher in all of the reactors. The measured and calculated $\mathrm{A}_{0}$ and $\mathrm{A}_{\max }$ values were determined to be close for each compound in each reactor. These results support the fitness of the data to Gompertz Model. $\mathrm{m}$ value is the slope and represents the increase of the concentration of the phenolic compound in groundwater by time. Since 2,4,6-TCP concentrations were higher in the groundwater samples, $m$ values of these compounds were found to be higher than that of the other phenolic compounds in each reactor. In the reactors, $\mathrm{m}$ values of PCP and 2,4,6 TCP were determined to be higher, except for R3 reactor consisting bentonite and clay in the liner system. It can be said from PCP, 2,4,6-TCP results that bentonite adsorbs these phenolic compounds. $m$ values of 2-CP and 4-NP compounds were determined to be lower in R3 and R4 reactors. It can be concluded that the rate of increase of 2-CP and 4-NP concentrations in groundwater samples of R3 and R4 reactors was found to be lower. This can be explained with the adsorption of these compounds by zeolite and bentonite materials used as a liner material in R3 and R4 reactors. Zeolite and bentonite 
reduces the transport rate of the 2-CP and 4-NP compounds from leachate to groundwater. It can be concluded from the results that in all of the reactors, $\mathrm{L}$ values of 2-CP were determined to be higher than that of the other phenolic compounds. Since L constant represents the time for the beginning of the increase of the concentration, it can be said that transport of 2-CP from leachate to groundwater through alternative composite liners consisting of clay, zeolite and bentonite materials takes more time when compared with other phenolic compounds.

\section{Acknowledgement}

This research has been supported by The Scientific and Technological Research Council of Turkey (TUBITAK - CAYDAG) (Project Number: 105Y334) Ankara-Turkey.

\section{References}

[1] Kjeldsen P, Barlaz, M.A., Rooker A.P., Baun A., Ledin A. \& Christensen T.H., Present and long-term composition of MSW landfill leachate: A Review. Critical Reviews in Environmental Science and Technology, 32 (4), pp. 297-336, 2002.

[2] Christensen T.H., Kjeldsen P., Bjerg P.L., Jensen D.L., Christensen J.B. \& Baun A., Biogeochemistry of landfill leachate plumes. Applied Geochemistry, 16, pp. 659-718, 2001.

[3] Baun D.L. \& Christensen T.H., Speciation of heavy metals in landfill leachate: a review. Waste Management Research, 22, pp. 3-23, 2004.

[4] Oman C.B. \& Junestedt C., Chemical characterization of landfill leachates400 parameters and compounds. Waste Management, 28, pp.1876-91, 2008.

[5] Slack, R.J., Gronow, J.R. \& Voulvoulis, N., Household hazardous waste in municipal landfills: contaminants in leachate. Science of the Total Environment, 337(1-3), pp.119-137, 2005.

[6] Bejerg, P.L., Tuxen, N., Reitzel, L.A., Albrechtsen, H.J. \& Kjeldsen, P., Natural attenuation processes in landfill leachate plumes at three Danish sites, 2009.

[7] Boopathy, R., Anaerobic phenol degradation by microorganisms of swine manure. Current Microbiology, 35, pp. 64-67, 1997.

[8] Boyd, S.A., Shelton, D.R., Berry, D. \& Tiedje, J.M., Phenolic compounds in digested sludge. Applied and Environmental Microbiology, 46, pp. 50 54, 1983.

[9] Paxéus, N., Organic compounds in municipal landfill leachates. Water Science and Technology, 41, pp. 323-333, 2000.

[10] United States Environmental Protection Agency (USEPA), Ambient water quality criteria for ammonia 440/5-85-001, Criteria and Standards Division, Washington, DC, 1984. 
[11] Looser, M.O., Parriaux, A. \& Bensimon, M., Landfill underground pollution detection and characterization using inorganic traces. Water Research, 33, pp. 3609-3616, 1999.

[12] Fatta, D., Papadopoulos, A. \& Loizidou, M., A study on the landfill leachate and its impact on the groundwater quality of the greater area. Environmental Geochemistry and Health, 21, pp. 175-190, 1999.

[13] Abu-Rukah, Y. \& Al-Kofahi, O., The assessment of the effect of landfill leachate on ground-water quality-a case study: El-Akader landfill site-north Jordan. J. Journal of Arid Environments, 49 (3), pp. 615-630, 2001.

[14] Longe, E.O. \& Enekwechi, L.O., Investigation on groundwater impacts and influence of local hydrogeology on natural attenuation of leachate at a municipal landfill. Int. J. Environmental Science \& Technology, 4 (1), pp. 133-140, 2007.

[15] Saarela, J., Pilot investigations of surface parts of three closed landfills and factors affecting them. Environmental Monitoring and Assessment, 84, pp. 183-192, 2003.

[16] Rowe, R.K., Long-term performance of contaminant barrier systems. Geotechnique, 55 (9), pp. 631-678, 2005.

[17] Edil, T.B., A review of aqueous-phase VOC transport in modern landfill liners. Waste Management, 23, pp. 561-571, 2003.

[18] Joo, J.C., Nam, K. \& Kim, J.Y., Estimation of mass transport parameters of organic compounds through high density polyethylene geomembranes using a modified double compartment apparatus. Journal of Environmental Engineering, 131 (5), pp.790-799, 2005.

[19] Sangam, H.P. \& Rowe, R.K., Migration of dilute aqueous organic pollutants through HDPE geomembrane. Journal of Geotextile and Geomembranes, 19, pp. 329-357, 2001.

[20] Kim, J.Y., Edil, T.B. \& Park, J.K., Volatile organic compound (VOC) transport through compacted clay. Journal of Geotechnical and Geoenvironmental Engineering - ASCE, 127(2), pp.126-134, 2001.

[21] Foose, G.J., Benson, C.H. \& Edil, T.B., Comparison of solute transport in three composite liners. Journal of Geotechnical and Geoenvironmental Engineering - ASCE, 128 (5), pp.391-403, 2002.

[22] Kalbe, U., Muller, W., Berger, W. \& Eckardt, J., Transport of organic contaminants within composite liner systems. Applied Clay Science, 21, pp.67-76, 2002.

[23] Toupiol, C., Willingham, T.W., Valocchi, A.J., Werth, C.J., Krapac, I.G., Stark, T.D. \& Daniel, D.E., Long-term tritium transport through fieldscale compacted soil liner. Journal of Geotechnical and Geoenvironmental Engineering - ASCE, 128 (8), pp. 640-650, 2002.

[24] Willingham, T.W., Werth, C.J., Valocchi, A.J., Krapac, I.G., Toupiol, C., Stark, T.D. \& Daniel, D.E., Evaluation of multidimensional transport through a field-scale compacted soil liner, Journal of Geotechnical and Geoenvironmental Engineering - ASCE, 130 (9), pp.887-895, 2004.

[25] Bezza, A. \& Ghomari F., Nondestructive test to track pollutant transport into landfill liners. Environmental Geology, 57 (2), pp. 285-290, 2008. 
[26] Malusis, M.A. \& Shackelford, C.D., Predicting contaminant flux through a clay membrane barrier. Journal of Geotechnical and Geoenvironmental Engineering - ASCE, 130 (5), pp. 477-487, 2004.

[27] Demir, A., Bilgili, M.S. \& Ozkaya, B., Effect of leachate recirculation on refuse decomposition rates at landfill site: A case study. International Journal of Environmental Pollution, 21 (2), pp.175-187, 2004.

[28] Ribeiro, A., Neves, M.H., Almeida, M.F., Alves, A. \& Santos, L., Direct determination of chlorophenols in landfill leachates by solid-phase microextraction-gas chromatography-mass spectrometry. Journal of Chromatography, 975, pp.267-274, 2002. 